\title{
Sensitivity of APSIM/ORYZA model due to estimation errors in solar radiation
}

\author{
Alexandre Bryan Heinemann ( $\left.{ }^{1 *}\right)$; Pepijn A.J. van Oort (2); Diogo Simões Fernandes $\left({ }^{3}\right)$; Aline de \\ Holanda Nunes Maia $\left({ }^{4}\right)$ \\ (') Embrapa Arroz e Feijão, Caixa Postal 179, 75375-000 Santo Antônio de Goiás (GO), Brasil. \\ (2) Wageningen University, Department of Plant Sciences, Centre for Crop Systems Analysis, Wageningen, the Netherlands. \\ (3) SIMEHGO, Palácio Pedro L. Teixeira, Rua 82, s/nº 2. ${ }^{\circ}$ andar, Setor Sul, 74000-000 Goiânia (GO), Brasil. \\ (4) Embrapa Meio Ambiente, Rodovia SP 340 - Km 127,5, 13820-000 Jaguariúna (SP), Brasil. \\ (*) Corresponding author: alexandre.heinemann@embrapa.br
}

Received: Aug. 21, 2012; Accepted: Dec. 5, 2012

\begin{abstract}
Crop models are ideally suited to quantify existing climatic risks. However, they require historic climate data as input. While daily temperature and rainfall data are often available, the lack of observed solar radiation $\left(R_{s}\right)$ data severely limits sitespecific crop modelling. The objective of this study was to estimate $\mathrm{R}_{\mathrm{s}}$ based on air temperature solar radiation models and to quantify the propagation of errors in simulated radiation on several APSIM/ORYZA crop model seasonal outputs, yield, biomass, leaf area (LAI) and total accumulated solar radiation (SRA) during the crop cycle. The accuracy of the 5 models for estimated daily solar radiation was similar, and it was not substantially different among sites. For water limited environments (no irrigation), crop model outputs yield, biomass and LAI was not sensitive for the uncertainties in radiation models studied here. Key words: crop model, calibration, upland rice.
\end{abstract}

\section{Análise de sensibilidade do modelo APSIM/ORYZA na estimava de erros na radiação solar}

\section{Resumo}

Modelos de simulação de culturas são importantes para quantificar riscos climáticos. Esses modelos necessitam de dados climáticos como dados de entrada. Entretanto, dados diários de precipitação pluvial e temperatura são facilmente encontrados, enquanto dados de radiação solar $\left(R_{s}\right)$ limitam-se à aplicação de modelos de simulação de culturas. O objetivo deste estudo foi estimar a $\mathrm{R}_{\mathrm{s}}$ utilizando cinco modelos de estimativa de radiação solar com base na temperatura do ar e quantificar a propagação de erros na radiação simulada na produtividade, biomassa, área foliar e radiação solar acumulada durante o ciclo da cultura do arroz de terras altas simulados pelo modelo de simulação ORYZA/APSIM. A acurácia dos cinco modelos de estimativa da radiação solar foi similar e não foi diferente entre os diferentes locais. Para ambientes que ocorre estresse hídrico, as saídas do modelo ORYZA/APSIM produtividade, biomassa e índice de área foliar não foram sensíveis às incertezas provenientes da radiação solar estimadas neste estudo.

Palavras-chave: modelos de simulação, calibração, arroz de terras altas.

\section{INTRODUCTION}

During the last decade, demand for rice in Brazil as well as in the world has increased considerably. However, the area available for rice production in the South of Brazil is limited, largely due to environmental and social constraints, such as competing demands for freshwater, industry or domestic use. Hence there is increasing interest in the upland rice systems of the Brazilian savannahs. This region is characterized by high inter and intra annual yield variability as consequence of precipitation patterns: even during the rainy season, there is chance of water stress occurrence due to periods of no rain or rain amount below crop demand. Thus, better quantification of existing climatic risks is urgently needed (Maia et al., 2007) to provide the rice industry with information to better cope with existing climate variability and to adapt to likely future changes.

Crop models can be used to quantify effects of climate variability on yield variability and to explore options for coping with this variability (AKPONIKPÈA et al., 2011). The greatest limitation for crop model application in this region is the lack of climate data (Heinemann et al., 2008). Global radiation $\left(\mathrm{R}_{\mathrm{s}}\right)$ is the driving factor controlling photosynthesis and evapotranspiration and is consequently an important weather variable for various agro-ecological studies. The lack of observed $\mathrm{R}_{\mathrm{s}}$ data severely limits 
site-specific modelling of crop growth (Donatelli et al., 2003). $R_{s}$ at the earth surface depends on radiation at the top of the atmosphere $\left(\mathrm{R}_{\mathrm{a}}\right)$ which can be calculated from latitude and day of year, based on astronomic equations. How much of $\mathrm{R}_{\mathrm{a}}$ reaches the earth's surface depends on atmospheric transmissivity.

Several researchers have shown that atmospheric transmissivity can be estimated from maximum and minimum air temperatures (BRISTOW and CAMPBELL, 1984; Donatelli and Campbell, 1998; Donatelli et al., 2003; Hargreaves and Samani, 1985), with daily $\mathrm{R}_{\mathrm{s}}$ estimated with accuracies of 50 to $98 \%$, while Farhadi Bansoulem et al. (2009) using the Hargreaves equations found strong interannual variation in accuracies, with $\mathrm{R}^{2}$ values ranging from 0 to $55 \%$. As air temperature is recorded by all meteorological stations, temperature-based estimation methods are directly applicable in any region, provided that some years of $\mathrm{R}_{\mathrm{s}}$ data are available for calibration of empirical parameters amongst these models, the Bristow-Campbell is the most commonly used. Much of this work on estimation of $\mathrm{R}_{\mathrm{s}}$ is driven by the need for $R_{s}$ as an input to crop growth models. Few studies however have quantified the impact of errors in $\mathrm{R}_{s}$ on errors in yields. Quite consistently, these studies conclude that yields can be accurately simulated, even with considerable error in $\mathrm{R}$ (FARHADI BANSOULEH et al., 2009; XIE et al., 2003). However, as the accuracy depends on the crop, environment and growth models used, results cannot be readly generalized for other scenarios.

The objective of this study are: i) to estimate solar radiation ( $\mathrm{R}$ ) in Goiás State, Brazil, by calibrating the models proposed by Bristow and CAMPBELl (1984), Donatelli and Bellocchi (2001), Donatelli and Campbell (1998)(1), Donatelli et al. (2003) and Hargreaves and Samani (1985), and (ii) to quantify the propagation of errors in simulated $\mathrm{R}_{\mathrm{s}}$ on several APSIM/ORYZA crop model seasonal outputs, namely: the upland rice yield, biomass, leaf area and total accumulated solar radiation during the crop cycle.

\section{MATERIAL AND METHODS}

\section{APSIM/ORYZA Crop Model}

ORYZA2000 is an explanatory, dynamic eco-physiological simulation model for rice (BoumAN and VAN LAAR, 2006), integrated into APSIM (Agricultural Production Systems Simulator; Keating et al., 2003).
APSIM/ORYZA simulates rice phenology, leaf area development, biomass production, yield and nitrogen accumulation in response to environmental variables such as temperature, solar radiation, soil water content and nitrogen fertilizer management. In this study, water availability was simulated via APSIM-SoilWat2 module while crop water requirement, which is based on potential evapotranspiration, was computed in the APSIM-Eo module. The APSIM framework also includes a nitrogen and carbon dynamics module 'soilN'.

\section{Solar Radiation Models}

It was compared five models for estimating daily solar radiation $\left(\mathrm{R}_{\mathrm{S}}\right)$, namely: $\mathrm{BC}$ - BRISTOw and Campbell (1984); HG - Hargreaves (1981) modified by Hunt et al. (1998); CD ${ }^{(1)}$; DB - Donatelli and BeLlocChi (2001) and modular model DCBB Donatelli et al. (2003). Four amongst these models (BC, CD, DB and DCBB) estimate the actual atmospheric transmissivity for the ith day of the year as a function of clear sky transmissivity $(\tau)$ and daily maximum $\left(\mathrm{T}_{\max }\right)$ and minimum $\left(\mathrm{T}_{\min }\right)$ temperatures. $\tau$ was assumed to be equal to 0.75 as suggested by FLETCHER and Моот (2007).

$$
\begin{aligned}
\mathrm{R}_{\mathrm{sBC}}= & 0.75\left[1-\exp \left(\frac{-\mathrm{b} \Delta \mathrm{T}_{\mathrm{i}}^{\mathrm{c}}}{\Delta \mathrm{T}_{\mathrm{avg}}}\right)\right] R_{a} \\
\mathrm{R}_{\mathrm{sCD}}= & 0.75\left[1-\exp \left(-\mathrm{b}\left(0.017 \exp \left(\exp \left(-0.053 \Delta \mathrm{T}_{\mathrm{avg}}\right)\right)\right)\right.\right. \\
& \left.\left.\Delta \mathrm{T}_{\mathrm{i}}^{2} f_{1}\left(\mathrm{~T}_{\text {min }}\right)\right)\right] R_{a}
\end{aligned}
$$

$\mathrm{R}_{\mathrm{sDB}}=0.75\left[1-f_{2}(\mathrm{i})\right]\left[1-\exp \left(\frac{-\mathrm{b} \Delta \mathrm{T}_{\mathrm{i}}^{\mathrm{c}}}{\Delta \mathrm{T}_{\mathrm{avg}}}\right)\right] R_{a}$

$\mathrm{R}_{\text {sDCBB }}=0.75\left[1+f_{2}(\mathrm{i})\right]\left[\frac{-\mathrm{b} \Delta \mathrm{T}_{\mathrm{i}}^{2} f_{1}\left(\mathrm{~T}_{\text {min }}\right)}{\Delta \mathrm{T}_{\text {avg }}}\right] R_{a}$

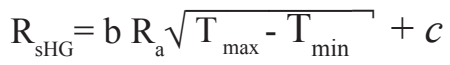

where $\mathrm{R}_{\mathrm{a}}$ is the daily potential radiation $\left(\mathrm{MJ} \mathrm{m}^{-2} \mathrm{day}^{-1}\right)$, calculated with standard astronomic equations based on day of year and latitude (GoudriaAn and VAN LAAR, 1994) $\Delta \mathrm{T}=\mathrm{T}_{\max }-\left(\mathrm{T}_{\min }+\mathrm{T}_{\min }+1\right) / 2, \Delta \mathrm{T}_{\text {avg }}$ is the mobile week temperature based on centred mobile 
mean (as the average over 7 days around) of maximum and minimum temperature $\left({ }^{\circ} \mathrm{C}\right)$; and $b$ and $c$ are parameters separately calibrated for each site and model. In equations $2-4$ two functions $f_{1}$ and $f_{2}$ are used:

$$
f_{1}\left(\mathrm{~T}_{\min }\right)=e^{\left(\frac{T_{\text {min }}}{T_{\text {ne }}}\right)}
$$

$f_{2(\mathrm{i})}=c_{1}\left[\sin \left(\mathrm{i} \times c_{2} \times \pi / 180\right)+\cos \left(\mathrm{i} \times f_{3}\left(c_{2}\right) \times \pi / 180\right)\right]$

where $T_{n c}$ is the summer night temperature factor to avoid underestimation of solar radiation in summer (Bechini et al., 2000); $\mathrm{i}=$ day of year, $c_{1}$ and $c_{2}$ are empirical model parameters for general seasonal factors (MaVromatis and Jagtap, 2005). In the equation defining $f_{2}(\mathrm{i}), f_{3}$ is calculated as:

$$
f_{3}\left(c_{2}\right)=1-1.9 \times c_{3}+3.83 \times c_{3}^{2}
$$

where $c_{3}=c_{2}-$ integer $\left(c_{2}\right)$. Empirical parameters were calibrated using daily radiation data of the even years, for each of the stations listed in table 1. Next, the models were validated using the odd year data. The parameters $b$ and $c$ for $\mathrm{BC}, \mathrm{CD}, \mathrm{DB}$ and DCBB models were estimated by ordinary least squares. For HG model, they were fitted by nonlinear least squares via the iterative method based on Gauss-Newton algorithm by using MASS package from R software (R Development Core Team, 2012: http://www.r-project.org). $T_{n c}, c_{1}$ and $c_{2}$ parameters were fitted by ordinary least squares based on $\mathrm{T}_{\min }\left(\mathrm{T}_{\mathrm{nc}}\right)$ and day of year $\left(c_{1}\right.$ and $\left.c_{2}\right)$ as described by Bellocchi et al. (2003) and Donatelli et al. (2004). All parameters were calibrated for each weather station separately.

A number of researchers have shown that $R_{s}$ values are also dependent on rainfall, altitude and latitude (Hunt et al., 1998, Weiss and Hays, 2004). It was plotted radiation model residuals against rainfall to investigate whether the models were biased or more inaccurate at the high and low rainfall levels.

\section{Data Collection and Crop Simulation}

Daily maximum and minimum temperatures and global solar radiation data from weather stations in Goiás state (Table 1) were provided by the Meteorological and Hydrological System of Goiás State (SIMEHGO "www.simego.sectec.go.gov.br/"). Data set available at each location ranged from 4 to 6 years. Data from even years was used for calibration of equations 1 to 8 and from odd ones for validation. The crop model APSIM/ORYZA for upland rice was calibrated to simulate crop responses environmental factors considering either observed or estimated solar radiation. Inputs to this model include daily weather data (minimum and maximum temperature, precipitation and solar irradiance), soil properties, initial soil water content, cultivar genetic characteristics, planting date, and $\mathrm{N}$ fertilizer management. The soil properties used as input for the crop model represent the most common soil type (Oxisols, covering 46\% of the upland rice region, Embrapa, 1999). We used characteristics of the most commonly grown cultivar in the region, BRS Primavera (Lorençoni et al., 2010). Model prognostic variables were simulated for nine locations and three planting dates, 1-Nov, 1-Dec and 31-Dec, corresponding to beginning, middle and end of planting season, respectively. The row spacing, plant density and nitrogen fertilization represent the local recommendation for upland rice in the region, $35 \mathrm{~cm}$, 200 plant $\mathrm{m}^{-2}$ and $20 \mathrm{~kg} \mathrm{ha}^{-1}$ of $\mathrm{N}$ at the planting date, $40 \mathrm{~kg} \mathrm{ha}^{-1}$ at begin of tillering, and $40 \mathrm{~kg} \mathrm{ha}^{-1}$ at begin of panicle initiation. Simulations started at least six months before each planting date in order to allow the establishment of a realistic soil water profile on the basis of rainfall patterns occurring before sowing because no irrigation was applied in the simulations. APSIM/ ORYZA seasonal outputs analyzed in this study were yield; maximum accumulated biomass; maximum leaf area index (LAI) and accumulated solar radiation during the crop cycle (SRA).

\begin{tabular}{|c|c|c|c|c|c|c|}
\hline ID & Weather Station name & Lat & Lon & Alt $(\mathrm{m})$ & Period & \# of years \\
\hline 01 & Ceres & -15.31 & -49.60 & 739 & $2002-2007$ & 6 \\
\hline 02 & Anápolis & -16.33 & -48.95 & 1136 & $2005-2008$ & 4 \\
\hline 03 & Anicuns & -16.46 & -49.96 & 692 & $2006-2009$ & 4 \\
\hline 04 & Vianópolis & -16.74 & -48.52 & 1110 & 2004-2007 & 4 \\
\hline 05 & Cristalina & -16.77 & -47.61 & 1189 & $2005-2008$ & 4 \\
\hline 06 & Palmeiras de Goiás & -16.80 & -49.93 & 596 & $\begin{array}{l}2000-2001 \\
2004-2005\end{array}$ & 4 \\
\hline 07 & Jandaia & -17.05 & -50.15 & 637 & $2005-2008$ & 4 \\
\hline 08 & Vicentinópolis & -17.74 & -49.81 & 648 & $2000-2005$ & 6 \\
\hline 09 & Jataí & -17.88 & -51.71 & 696 & 2004-2009 & 6 \\
\hline
\end{tabular}

Table 1. Weather station localization, altitude, period and number of years used in this study

ID: identification. Lat: latitude. Lon: longitude. Alt: altitude. 


\section{Model validation}

The accuracy of the solar radiation models was compared via descriptive statistics that indicate the degree of agreement between results based on either, monthly and daily observed or estimated solar irradiance as input data. The goodness of fit was assessed by the following measures: (i) parameter estimates (slope and intercept) of the regression line between estimated and measured values; (ii) correlation coefficient (r) (iii) the relative root mean squared error (RRMSE, equation 9), an indicator of the overall relative accuracy of the model; (iv) the systematic root mean square error (RMSEs), a measure of the model's linear (or systematic) bias (equation 10) and (v) the mean absolute error (MAE, equation 11), the arithmetic mean of absolute residuals. Small MAE values indicate a method with low overall mean error.

$$
\begin{aligned}
& \text { RRMSE }=100 x\left[\frac{\left(\left(\frac{1}{n}\right) \sum\left[\left(R_{e s t}-R_{o b s}\right)^{2}\right)^{0.5}\right]}{\sum \frac{R_{o b s}}{n}}\right] \\
& \text { RRMSEs }=\left[\frac{1}{n} \sum_{i=1}^{n}\left|\hat{R}_{e s t}-R_{o b s}\right|^{2}\right]^{0.5}
\end{aligned}
$$

$\mathrm{MAE}=\frac{1}{n} \sum_{i=1}^{n}\left|R_{e s t}-R_{o b s}\right|$

where $\mathrm{R}_{\mathrm{obs}}$ and $\mathrm{R}_{\text {est }}$ are, respectively, the observed and estimated daily solar radiation, $\mathrm{n}$ the number of days used for model fitting and $\hat{R}_{e s t}$ is the best estimate of the predicted quantity calculated with the intercept (a) and slope (b) of the least-squares regression between $R_{\text {obs }}$ and $\mathrm{R}_{\text {est }}, \hat{R}_{\text {est }}=\mathrm{a}+\mathrm{bx}_{\mathrm{i}}$.

To quantify the influence of inaccuracies in solar radiation estimates on APSIM/ORYZA seasonal outputs $(\mathrm{Y})$ the model was run once a time using observed radiation or radiation estimated by each radiation model, resulting in a pair $Y_{R \text {-obs }}$ and $Y_{\text {R-est }}$ values for each radiation model and output variable. Differences between $Y_{R \text {-obs }}$ and $Y_{R \text {-est }}$, here referred to as $\Delta Y$ were then calculated for yield, biomass, maximum leaf area index (LAI) and accumulated solar radiation (SRA). We assessed the discrepancies between $Y_{R-o b s}$ and $Y_{R \text {-est }}$ for each radiation model by several graphical and descriptive analysis: (i) box-and-whiskers plots of $\Delta \mathrm{Y}$ for displaying range of deviances, outliers and bias resulting from radiation estimation; (ii) deviance measures (r, MAE and RRMSE) previously described for evaluation of radiation models themselves and RMSE (root mean square error); (iii) similarity measures: the index of agreement d (Wilmotт, 1981; equation 12) and the coefficient of efficiency (NASH and Sutcliffe, 1970; equation 13) as joint measures of bias and accuracy and (iv) empirical cumulative distribution function (ecdf).

Thus what we present is a sensitivity analysis. The analysis shows how sensitive APSIM/ORYZA model output is to estimation errors in solar radiation. The accuracies reported therefore do not provide information on how good APSIM/ORYZA is at simulating actual yields. In this study model accuracy is considered excellent when RRMSE $<10 \%$; good if $10 \% \leq \mathrm{RRMSE}<20 \%$; fair if $20 \% \leq \mathrm{RRMSE}<30 \%$; and poor if RRMSE $\geq 30 \%$ (JAMIESON et al., 1991); $d$ and $\mathrm{E}$ are summary measures which accounts for accuracy. They range from 0 to 1 and minus infinity to 1 , respectively. Basically, d represents the ratio between the mean square error and the "potential error" (Willmot, 1984) and E determines the relative magnitude of the residual variance ("noise") compared to the measured data variance ("information") (Moriasi et al., 2007). For both similarity measures, higher values indicate better agreement.

$\mathrm{d}=1-\left(\frac{\sum_{i=1}^{n}\left(Y_{R_{\text {olos }}}-Y_{R_{- \text {est }}}\right)^{2}}{\sum_{n}^{i}\left(\left|Y_{R_{- \text {est }}}-\bar{Y}_{R_{-o b s}}\right|+\left|Y_{R_{-o b s}}-\bar{Y}_{R_{-o b s}}\right|\right)^{2}}\right)$

$\mathrm{E}=1-\left(\frac{\sum_{i=1}^{n}\left(Y_{R_{o b s}}-Y_{R_{e s t}}\right)^{2}}{\sum_{i=1}^{n}\left(Y_{R_{o b s}}-\bar{Y}_{R_{e s t}}\right)^{2}}\right)$

The ecdf functions for the observed $\left(\mathrm{Y}_{\mathrm{R} \text {-obs }}\right)$ and estimated $\left(\mathrm{Y}_{\mathrm{R} \text {-ess }}\right)$ seasonal crop model outputs (yield, biomass, LAI and SRA) was calculated and the maximum vertical distance between $Y_{R \text {-obs }}$ and $Y_{R \text {-est }}$ ecdf's was determined by the Kolmogorov-Smirnov test (K-S).

\section{RESULTS AND DISCUSSION}

In the study region, the daily air temperature range increases from April, the beginning of the dry period, to August, which is the top of dry period and decrease from September, begin of the wet period, to December. For upland rice, the planting window is from November to December and rice is harvested in April. This period shows the lowest daily temperature range.

The local empirical parameter estimates obtained for the five models are described in table 2. Few papers actually report estimated values for these parameters. The parameter estimates listed here for the CD and DB models are similar to the ones described by Bellocchi et al. (2003). However, for the BC model, $b$ parameter 
Table 2. Parameter estimates of solar radiation models at each location (wheather station)

\begin{tabular}{|c|c|c|c|c|c|c|c|c|c|c|}
\hline \multirow{2}{*}{ Model } & \multirow{2}{*}{$\begin{array}{c}\text { Empirical } \\
\text { Parameters }\end{array}$} & \multicolumn{9}{|c|}{ Weather Station ID } \\
\hline & & 1 & 2 & 3 & 4 & 5 & 6 & 7 & 8 & 9 \\
\hline \multirow{2}{*}{$B C$} & $b$ & 0.96 & 0.70 & 0.75 & 0.69 & 0.39 & 0.87 & 1.93 & 0.42 & 0.94 \\
\hline & c & 1.38 & 1.60 & 1.59 & 1.47 & 1.89 & 1.36 & 1.12 & 1.71 & 1.42 \\
\hline$C D$ & $b$ & 0.13 & 0.46 & 0.42 & 0.18 & 0.51 & 0.13 & 0.13 & 0.30 & 0.23 \\
\hline \multirow{3}{*}{ DB } & $b$ & 0.20 & 0.28 & 0.28 & 0.19 & 0.30 & 0.17 & 0.24 & 0.21 & 0.24 \\
\hline & $c_{1}$ & 0.04 & -0.02 & 0.00 & 0.05 & -0.06 & 0.04 & 0.06 & 0.02 & 0.01 \\
\hline & $c_{2}$ & 1.41 & 1.46 & 1.22 & 0.46 & 1.46 & 0.76 & 1.03 & 0.74 & 0.74 \\
\hline \multirow{3}{*}{ DCBB } & $b$ & 0.17 & 0.24 & 0.23 & 0.16 & 0.26 & 0.14 & 0.20 & 0.17 & 0.20 \\
\hline & $c_{1}$ & 0.04 & -0.02 & 0.00 & 0.04 & -0.06 & 0.04 & 0.05 & 0.01 & 0.01 \\
\hline & $c_{2}$ & 1.41 & 1.46 & 1.22 & 0.46 & 1.46 & 0.76 & 1.03 & 0.74 & 0.74 \\
\hline \multirow{2}{*}{ HG } & $b$ & 0.18 & 0.17 & 0.18 & 0.18 & 0.16 & 0.17 & 0.17 & 0.14 & 0.18 \\
\hline & c & -4.80 & -0.07 & -1.98 & -3.69 & 1.42 & -4.03 & -2.15 & 0.82 & -2.71 \\
\hline
\end{tabular}

BC: Bristow-Campbell; HG: Hargreaves; CD: Donatelli-Campbell; DB: Donatalli-Bellocchi and DCBB: modular model

Table 3. Accuracy of solar radiation models by site as measured by overall model mean of the following measures

\begin{tabular}{|c|c|c|c|c|c|c|c|c|c|c|c|c|c|}
\hline \multirow{2}{*}{ Model } & \multicolumn{13}{|c|}{ Wheater Station ID } \\
\hline & & & 1 & 2 & 3 & 4 & 5 & 6 & 7 & 8 & 9 & Mean & S.D. \\
\hline \multirow{8}{*}{ BC } & \multirow{4}{*}{ Calibration } & RRMSE & 11.58 & 12.31 & 12.62 & 16.1 & 13.06 & 9.92 & 11.4 & 13.3 & 13.09 & 12.5 & 1.63 \\
\hline & & MAE & 2.3 & 2.73 & 2.69 & 3.08 & 2.93 & 2.05 & 2.38 & 2.43 & 2.57 & 2.55 & 0.31 \\
\hline & & $r$ & 0.78 & 0.69 & 0.74 & 0.71 & 0.72 & 0.83 & 0.73 & 0.74 & 0.77 & 0.75 & 0.04 \\
\hline & & RMSES & 3.09 & 3.62 & 3.51 & 4.25 & 3.72 & 2.55 & 3.22 & 3.11 & 3.43 & 3.39 & 0.45 \\
\hline & \multirow{4}{*}{ Validation } & RRMSE & 11.76 & 14.93 & 12.95 & 15.7 & 15.16 & 11.48 & 13.3 & 14.9 & 13.45 & 13.72 & 1.44 \\
\hline & & MAE & 2.35 & 2.79 & 2.8 & 3.06 & 2.83 & 2.24 & 2.31 & 2.85 & 2.66 & 2.67 & 0.28 \\
\hline & & $r$ & 0.77 & 0.70 & 0.69 & 0.71 & 0.73 & 0.81 & 0.75 & 0.71 & 0.73 & 0.73 & 0.04 \\
\hline & & RMSES & 3.12 & 3.57 & 3.62 & 3.93 & 3.44 & 2.90 & 3.00 & 3.48 & 3.53 & 3.40 & 0.31 \\
\hline \multirow{8}{*}{$C D$} & \multirow{4}{*}{ Calibration } & RRMSE & 12.06 & 12.72 & 13.05 & 16.2 & 13.3 & 10.27 & 12.5 & 13.6 & 13.59 & 12.93 & 1.51 \\
\hline & & MAE & 2.37 & 2.76 & 2.71 & 3.1 & 2.99 & 2.06 & 2.59 & 2.5 & 2.64 & 2.62 & 0.3 \\
\hline & & $r$ & 0.79 & 0.69 & 0.74 & 0.72 & 0.72 & 0.84 & 0.73 & 0.75 & 0.77 & 0.75 & 0.04 \\
\hline & & RMSEs & 3.04 & 3.57 & 3.48 & 4.13 & 3.70 & 2.50 & 3.18 & 3.07 & 3.43 & 3.34 & 0.44 \\
\hline & \multirow{4}{*}{ Validation } & RRMSE & 12.14 & 15.61 & 13.40 & 16.00 & 15.53 & 11.19 & 14.4 & 15.1 & 14.11 & 14.14 & 1.56 \\
\hline & & MAE & 2.42 & 2.84 & 2.8 & 3.03 & 2.91 & 2.16 & 2.43 & 2.88 & 2.76 & 2.71 & 0.28 \\
\hline & & $r$ & 0.77 & 0.71 & 0.69 & 0.70 & 0.73 & 0.81 & 0.75 & 0.73 & 0.73 & 0.74 & 0.04 \\
\hline & & RMSES & 3.14 & 3.55 & 3.60 & 3.98 & 3.44 & 2.84 & 3.03 & 3.39 & 3.54 & 3.39 & 0.32 \\
\hline \multirow{8}{*}{ DB } & \multirow{4}{*}{ Calibration } & RRMSE & 12.82 & 12.72 & 13 & 16.5 & 13.04 & 12.07 & 11.9 & 13.6 & 13.96 & 13.16 & 1.35 \\
\hline & & MAE & 2.54 & 2.73 & 2.68 & 3.09 & 2.85 & 2.53 & 2.45 & 2.49 & 2.71 & 2.65 & 0.2 \\
\hline & & $r$ & 0.77 & 0.69 & 0.74 & 0.71 & 0.73 & 0.80 & 0.75 & 0.75 & 0.77 & 0.75 & 0.03 \\
\hline & & RMSEs & 3.14 & 3.61 & 3.47 & 4.25 & 3.84 & 2.68 & 2.95 & 3.10 & 3.50 & 3.39 & 0.45 \\
\hline & \multirow{4}{*}{ Validation } & RRMSE & 12.58 & 15.49 & 13.24 & 17 & 15.53 & 11.92 & 14.2 & 15.4 & 14.47 & 14.37 & 1.54 \\
\hline & & MAE & 2.58 & 2.8 & 2.77 & 3.25 & 2.88 & 2.31 & 2.4 & 2.96 & 2.81 & 2.76 & 0.27 \\
\hline & & $r$ & 0.75 & 0.71 & 0.69 & 0.66 & 0.73 & 0.79 & 0.75 & 0.71 & 0.72 & 0.72 & 0.04 \\
\hline & & RMSES & 3.20 & 3.56 & 3.58 & 4.01 & 3.49 & 3.00 & 3.00 & 3.39 & 3.54 & 3.42 & 0.30 \\
\hline \multirow{8}{*}{ DCBB } & \multirow{4}{*}{ Calibration } & RRMSE & 14.56 & 12.75 & 12.99 & 17.6 & 13.15 & 15.69 & 13.7 & 14.1 & 15.18 & 14.19 & 1.63 \\
\hline & & MAE & 2.98 & 2.73 & 2.7 & 3.2 & 2.84 & 3.33 & 2.93 & 2.58 & 2.96 & 2.88 & 0.26 \\
\hline & & $r$ & 0.77 & 0.69 & 0.75 & 0.70 & 0.72 & 0.83 & 0.77 & 0.75 & 0.76 & 0.75 & 0.04 \\
\hline & & RMSES & 3.14 & 3.61 & 3.47 & 4.25 & 3.84 & 2.68 & 2.95 & 3.10 & 3.63 & 3.41 & 0.46 \\
\hline & \multirow{4}{*}{ Validation } & RRMSE & 14.72 & 15.51 & 13.22 & 17 & 15.38 & 16.21 & 16.8 & 16.2 & 15.77 & 15.49 & 1.19 \\
\hline & & MAE & 3.00 & 2.79 & 2.78 & 3.28 & 2.86 & 3.23 & 2.92 & 3.10 & 3.05 & 2.99 & 0.17 \\
\hline & & $r$ & 0.73 & 0.71 & 0.69 & 0.64 & 0.73 & 0.79 & 0.76 & 0.71 & 0.72 & 0.72 & 0.04 \\
\hline & & RMSES & 3.28 & 3.56 & 3.58 & 4.15 & 3.49 & 3.08 & 3.00 & 3.50 & 3.63 & 3.47 & 0.32 \\
\hline \multirow{8}{*}{ HG } & \multirow{4}{*}{ Calibration } & RRMSE & 11.82 & 13.14 & 13.24 & 16.7 & 14.88 & 10.3 & 11.5 & 15.3 & 13.58 & 13.43 & 1.91 \\
\hline & & MAE & 2.43 & 3.07 & 2.91 & 3.37 & 3.54 & 2.10 & 2.46 & 2.84 & 2.73 & 2.84 & 0.44 \\
\hline & & $r$ & 0.77 & 0.62 & 0.70 & 0.68 & 0.58 & 0.81 & 0.72 & 0.62 & 0.75 & 0.70 & 0.08 \\
\hline & & RMSES & 3.16 & 3.89 & 3.72 & 4.40 & 4.34 & 2.66 & 3.27 & 3.63 & 3.56 & 3.63 & 0.52 \\
\hline & \multirow{4}{*}{ Validation } & RRMSE & 12.52 & 16.12 & 13.47 & 16.7 & 16.91 & 12.53 & 13.5 & 15.8 & 13.78 & 14.65 & 1.68 \\
\hline & & MAE & 2.56 & 3.15 & 2.99 & 3.48 & 3.34 & 2.57 & 2.39 & 3.04 & 2.84 & 2.97 & 0.37 \\
\hline & & $r$ & 0.73 & 0.62 & 0.66 & 0.66 & 0.61 & 0.75 & 0.74 & 0.66 & 0.71 & 0.68 & 0.05 \\
\hline & & RMSES & 3.34 & 3.90 & 3.78 & 4.19 & 4.02 & 3.20 & 3.09 & 3.73 & 3.62 & 3.65 & 0.35 \\
\hline
\end{tabular}


was higher (0.42 to 1.93$)$ than the one reported in BeLlocCHI et al. (2003), ranging from 0.08 to 0.6. According to Liu et al. (2008), for the BC model, $b$ parameter is more affected than $c$ by different ways of calculating the monthly mean temperature $(\Delta \mathrm{T} m)$ correction. In this study, $\Delta \mathrm{T} m$ was calculated as centred week mobile average $\left(\Delta \mathrm{T}_{\text {avg }}\right)$. Also we did not have set the $c$ parameter as fixed for the BC model, but calibrated it separately for each location. Parameter $c$ ranged from 1.12 to 1.89 . For the HG model, parameters $b$ and $c$ are similar to those ones found by Liu et al. (2008). They ranged from 0.14 to 0.18 and -4.80 to 1.42 , respectively.

The accuracy of the five models evaluated (Equations 1-5) was similar (Table 3): based on the average RRMSE values (Table 3) all were classified as good. The BC model showed the lowest mean RMSE and MAE values for calibration as well as validation. $\mathrm{BC}$ and $\mathrm{CD}$ model showed the lowest mean systematic error values (RMSEs) for calibration and validation. Considering all data set (Figure 1a-e), the $r$ (a)

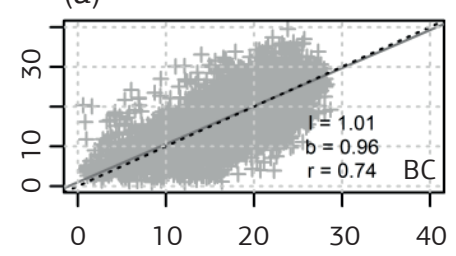

(b)

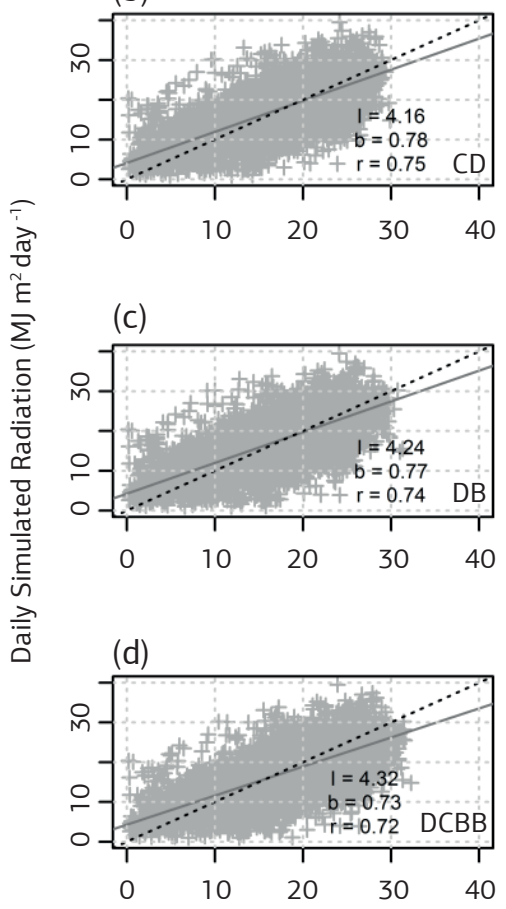

(e)

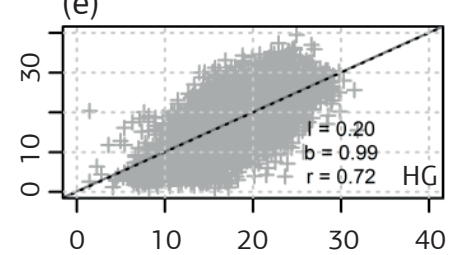

Daily Observed Radiation (MJ $\mathrm{m}^{2}$ day $^{-1}$ ) (f)

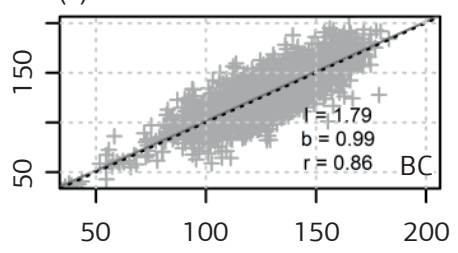

(g)
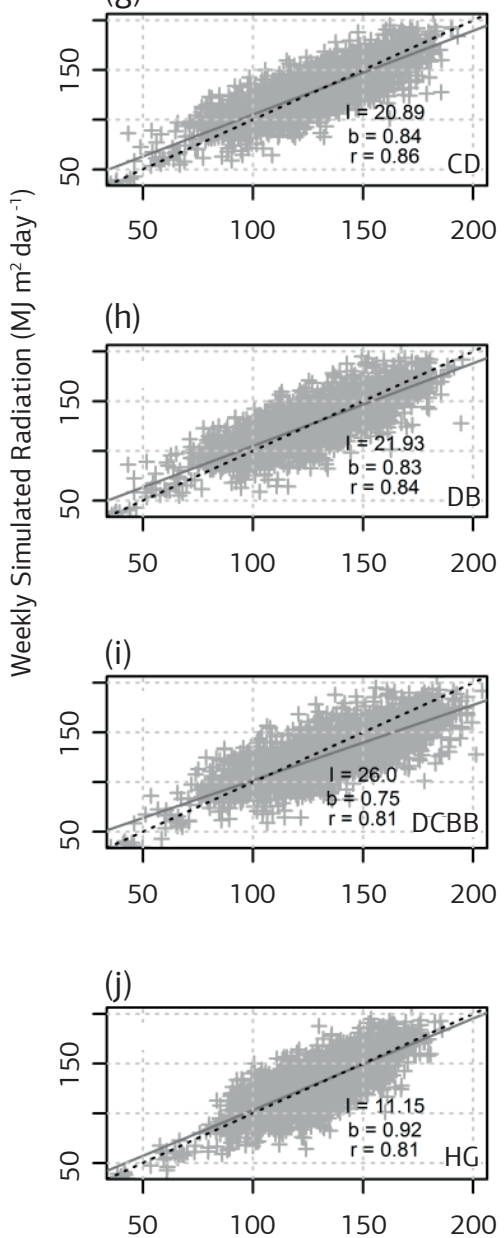

Weekly Observed Radiation (MJ m² day $^{-1}$ ) (k)

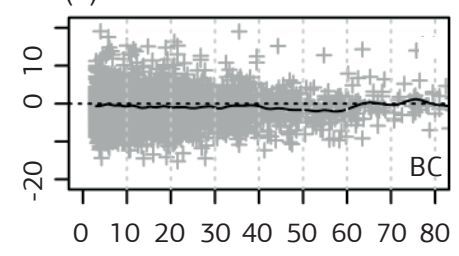

(l)

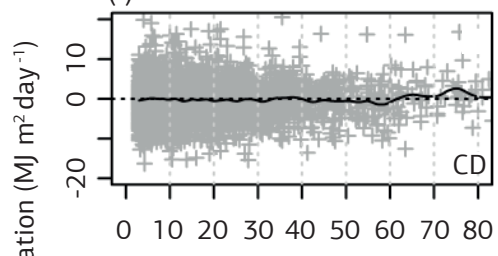

(m)

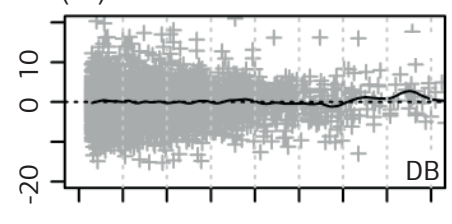

$0 \quad 1020304050607080$

(n)

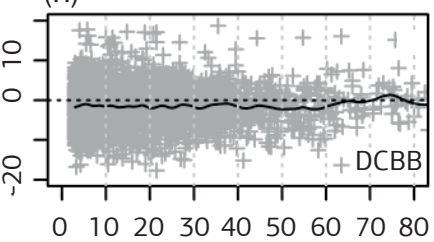

(o)

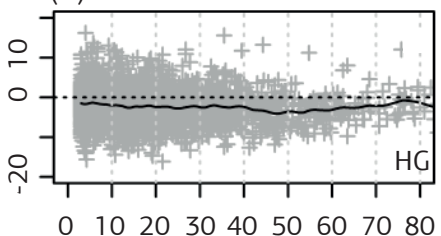

Rainfall (mm)

Figure 1. Scatterplots for daily observed radiation versus daily simulated radiation (a-e), weekly observed radiation versus weekly simulated radiation $(\mathrm{f}-\mathrm{j})$, being the black dashed line the $1: 1$ and gray full line the fitted regression line and $\mathrm{I}$ is the intercepted, $\mathrm{b}$ the slope and $\mathrm{r}$ the coefficient of determination for the regression line Scatterplots at the right colums of the panel $(\mathrm{k}-\mathrm{o})$ show difference between daily observed and simulated radiation for each model, as function of daily rainfall amount. BC: Bristow and Campbell; HG: Hargreave; CD: Donatelli and Campbell; DB: Donatelli \& Bellocchi and DCBB: modular model. 
ranged from 0.72 to 0.75 . These values are lower than the ones found in European studies (TRNkA et al., 2005), but similar to values presented in a Northern Australian study (LiU and Scotr, 2000) and some values obtained from locations in North America (BALL et al., 2004). The CD model showed the highest degree of linear relationship between measured and simulated $\mathrm{R}_{\mathrm{s}}$ (highest $\mathrm{r}$ value) followed by the $\mathrm{BC}$ and DB models (Figure 1b). Comparing the slopes and intercepts of the linear regressions between daily measured and predicted $\mathrm{R}$, the HG model showed the slope (b) and intercepted (I) closest to 1 and 0 , respectively, followed by the BC model (Figure 1a,e). The weekly aggregation of measured and predicted radiation values (Figure $1 \mathrm{f}-\mathrm{j}$ ) lead to increased $\mathrm{r}$ (0.81 to 0.86$)$, minimizing the discrepancy. In this case, the BC and CD models showed the highest degree of agreement between measured and simulated $\mathrm{R}_{\mathrm{s}}$ (highest $\mathrm{r}$ value) followed by the $\mathrm{DB}$ model. The $\mathrm{BC}$ model showed the slope and intercept closest to 1 and 0 , respectively (Figure 1f). The highest residuals for all radiation models (Figure $1 \mathrm{k}-\mathrm{o}$ )) corresponded to days with low rainfall values $(\leq 10 \mathrm{~mm})$. The BC, CD, DB and DCDB models had the cubic smoothing spline regression parallel the zero residual line, showing no relationship between bias and rainfall. The HG and DCBB overestimated radiation under rainfall. Probably, adding rainfall variable in these two models will improve their performance under rainfall days.

\section{Impact of estimated solar radiation on simulated crop model output}

Considering pooled data from all weather stations, all evaluated radiation models (Equations 1-5) were classified in same class of accuracy (RRMSE $<10 \%$ ) for predicting yield, biomass and SRA (Table 4) whi$\mathrm{ch}$ is not surprising considering that they simulated $\mathrm{R}_{\mathrm{s}}$ with similar accuracies (Table 3). Only the HG model, for maximum LAI showed an RRMSE higher than $10 \%$. In this study, all crop models outputs showed RMSE higher than MAE (Table 4). The ratio RMSE/ MAE is an indicator of regression outliers (LEGATES and McCabe, 1999). The highest difference between RMSE and MAE for yield was observed for BC model $\left(80 \mathrm{~kg} \mathrm{ha}^{-1}\right)$ and the lowest for the HG model (68 $\left.\mathrm{kg} \mathrm{ha}^{-1}\right)$. The HG model also showed the highest $\mathrm{r}$ for yield (0.99). All radiation models resulted in similar values for the index of agreement (d) for yield (Table 4). However, the coefficient of efficiency (E) for yield was different among models. Based on this index, the best models for estimated radiation to predict yield are $\mathrm{BC}, \mathrm{CD}$ and $\mathrm{DCBB}$. The use of daily solar radiation estimated by BC and HG as input to APSIM/ORYZA leads to overestimation of yield as characterized by boxes bellow the zero line (high frequency of $Y_{R \text {-obs }}<Y_{R \text {-ess }}$ ) in Figure 2.

Conversely, when radiation was estimated via the $\mathrm{CD}, \mathrm{DB}$ and DCBB models, the referred output variables showed an underestimation tendency. For maximum biomass, the highest difference between RMSE and MAE was observed for the DCBB model $(151 \mathrm{~kg}$ $\left.\mathrm{ha}^{-1}\right)$ and the lowest for the BC model $\left(92 \mathrm{~kg} \mathrm{ha}^{-1}\right)$. In this case the $\mathrm{BC}$ and $\mathrm{HG}$ models showed the highest $\mathrm{r}$ (0.97) (Table 4). Based on d, the best models were BC, $\mathrm{CD}$ and DCBB. Nevertheless, BC model showed the highest $\mathrm{E}$. BC and HG models also leads to overestimate the maximum biomass as showed in Figure 2b, being the degree of overestimation higher for HG. For maximum LAI, the HG model accounted for the highest

Table 4. Measures of agreement among APSIM/ORYZA outputs (yield, biomass, maximum LAI and solar radiation accumulated (SRA) during the crop cycle) simulated using either observed radiation or radiation estimated by empirical models

\begin{tabular}{|c|c|c|c|c|c|c|}
\hline & & Yield & Biomass & LAI & SRA & Average \\
\hline \multirow{6}{*}{$B C$} & RRMSE & 6.9 & 4.1 & 5.9 & 5.3 & 5.6 \\
\hline & RMSE & 261 & 493 & 0.22 & 104 & 215 \\
\hline & MAE & 181 & 401 & 0.16 & 82 & 166 \\
\hline & $r$ & 0.97 & 0.97 & 0.95 & 0.62 & 0.88 \\
\hline & $d$ & 0.99 & 0.99 & 0.99 & 0.98 & 0.99 \\
\hline & E & 0.97 & 0.96 & 0.95 & 0.59 & 0.87 \\
\hline \multirow{6}{*}{ CD } & RRMSE & 7.4 & 5.3 & 7.4 & 5.4 & 6.4 \\
\hline & RMSE & 279 & 636 & 0.27 & 106 & 255 \\
\hline & MAE & 212 & 497 & 0.21 & 86 & 199 \\
\hline & $r$ & 0.93 & 0.96 & 0.94 & 0.65 & 0.87 \\
\hline & $d$ & 0.99 & 0.99 & 0.99 & 0.97 & 0.99 \\
\hline & $E$ & 0.97 & 0.95 & 0.92 & 0.56 & 0.85 \\
\hline \multirow{6}{*}{ DB } & RRMSE & 8.3 & 6 & 8.4 & 6.7 & 7.4 \\
\hline & RMSE & 316 & 723 & 0.31 & 129 & 292 \\
\hline & MAE & 245 & 581 & 0.24 & 105 & 233 \\
\hline & $r$ & 0.96 & 0.96 & 0.93 & 0.58 & 0.86 \\
\hline & d & 0.99 & 0.98 & 0.98 & 0.92 & 0.97 \\
\hline & E & 0.96 & 0.93 & 0.89 & 0.34 & 0.78 \\
\hline \multirow{6}{*}{ DCBB } & RRMSE & 7.2 & 5.2 & 7.1 & 9.9 & 7.4 \\
\hline & RMSE & 272 & 621 & 0.26 & 192 & 271 \\
\hline & MAE & 197 & 470 & 0.19 & 155 & 206 \\
\hline & $r$ & 0.97 & 0.96 & 0.93 & 0.34 & 0.80 \\
\hline & $d$ & 0.99 & 0.99 & 0.99 & 0.92 & 0.97 \\
\hline & E & 0.97 & 0.95 & 0.92 & -0.41 & 0.61 \\
\hline \multirow{6}{*}{ HG } & RRMSE & 8.9 & 8.6 & 10.3 & 6.7 & 8.6 \\
\hline & RMSE & 331 & 1028 & 0.41 & 130 & 372 \\
\hline & MAE & 273 & 880 & 0.32 & 104 & 314 \\
\hline & $r$ & 0.98 & 0.97 & 0.95 & 0.6 & 0.88 \\
\hline & d & 0.99 & 0.96 & 0.96 & 0.93 & 0.96 \\
\hline & $E$ & 0.95 & 0.86 & 0.82 & 0.34 & 0.74 \\
\hline
\end{tabular}

RRMSE: relative root mean square error (\%). RMSE: root mean square error (for yield and biomass $\mathrm{kg} \mathrm{ha}^{-1}$, for SRA MJ m² $\left.\mathrm{day}^{-1}\right)$.

MAE: mean absolute error (for yield and biomass $\mathrm{kg} \mathrm{ha}^{-1}$, for SRA MJ $\mathrm{m}^{2} \mathrm{day}^{-1}$ ). $r$ : correlation coefficient. d: -index of agreement. E: coefficient of efficiency. BC: Bristow-Campbell; HG: Hargreaves; CD: Donatelli-Campbell; DB: DonatalliBellocchi and DCBB: modular model 
(a)

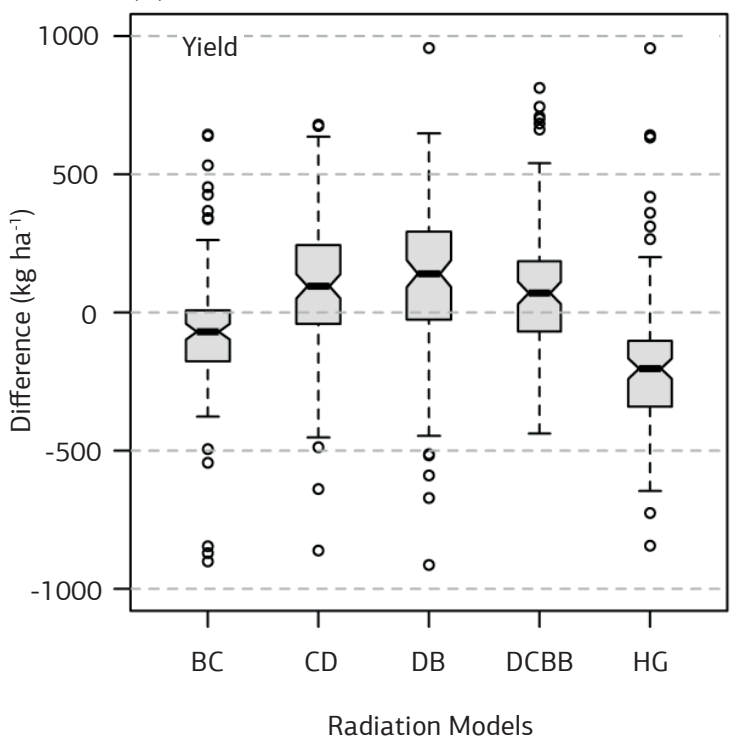

(b)

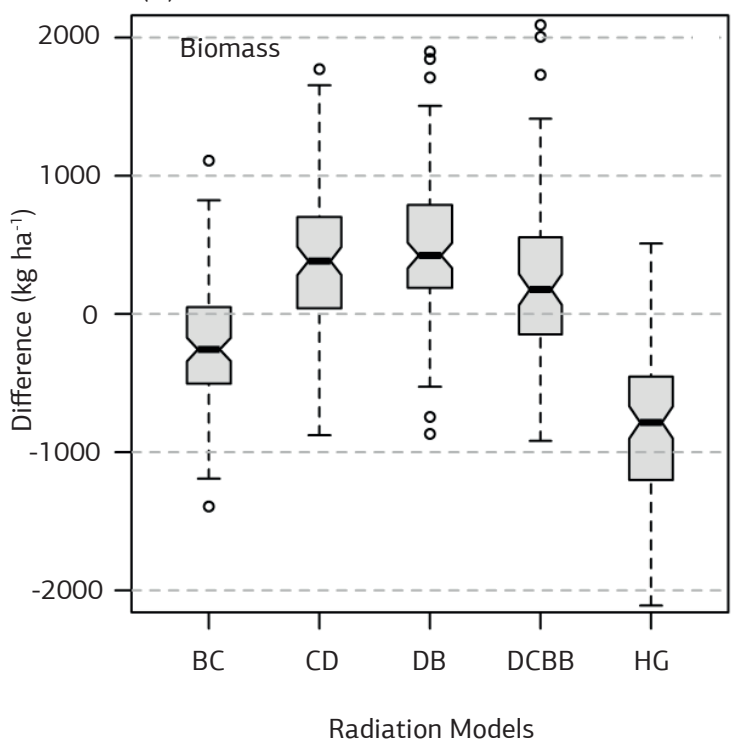

(c)

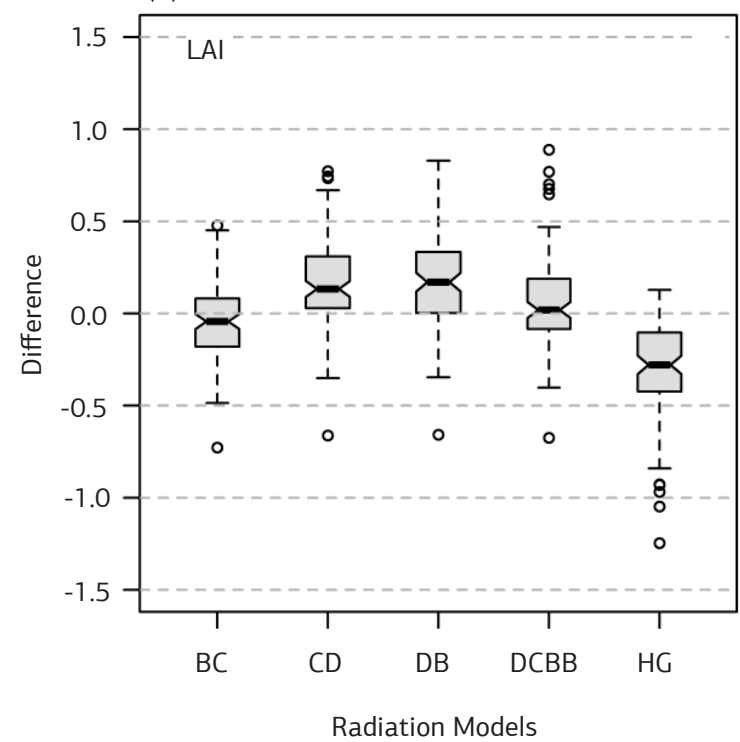

(d)

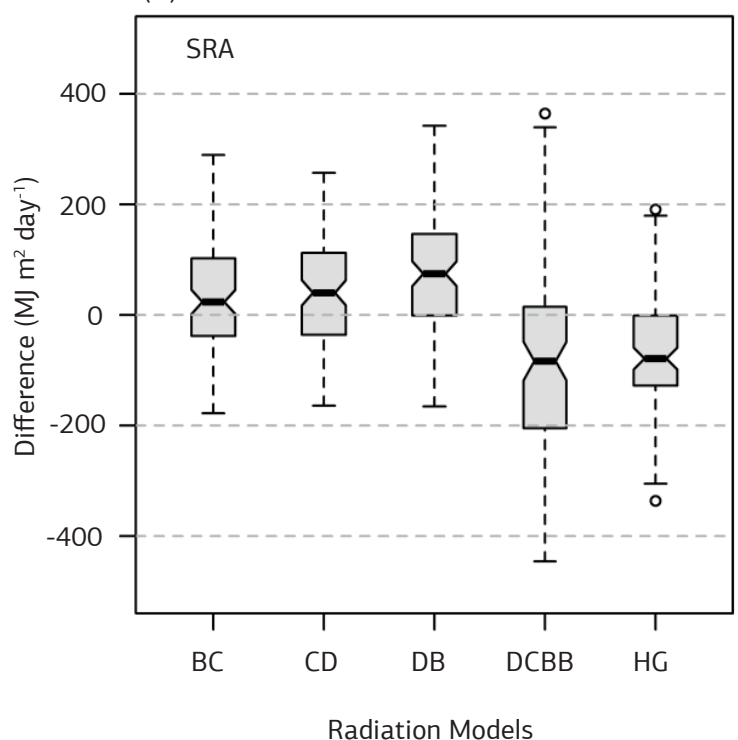

Figure 2. Box plot for crop model output difference $\Delta \mathrm{Y}$ (model output using observed daily radiation minus respective model output using simulated daily radiation), considering pooled data from locations and planting dates for (a) simulated yield, (b) simulated Biomass, (c) simulated max LAI and (d) simulated SRA (solar radiation accumulated during crop cycle). BC: Bristow and Campbell; CD: Donatelli and Campbell; DB: Donatelli and Bellocchi; DCBB: modular model and HG: Hargreave. The bottom and top edges of the box are located at the $25^{\text {th }}$ and $75^{\text {th }}$ sample percentiles of $\Delta Y$. The center horizontal line is drawn at the median and the black dot, at the mean. The vertical lines, or whiskers, extends from the box as far as the data extend, to a distance at most 1.5 interquartile range.

difference between RMSE and MAE (0.10) and the lowest difference by the $\mathrm{BC}$ and $\mathrm{CD}$ models (0.06). The $\mathrm{BC}$ and $\mathrm{HG}$ had the highest $\mathrm{r}$ values. According to $\mathrm{d}$, the best models for maximum LAI were $\mathrm{BC}$, $\mathrm{CD}$ and DCBB. Based on E, the best model was BC (Table 4). For this crop model output, BC and HG models showed the same trend as yield and biomass. Both models leads to overestimate the maximum LAI as showed in Figure 2c. However, the degree of overestimation is higher for the HG model. For SRA, the DCBB model accounted for the highest difference between RMSE and MAE (37 MJ m ${ }^{2}$ day $\left.^{-1}\right)$. The CD model showed the lowest difference $\left(20 \mathrm{MJ} \mathrm{m}^{2}\right.$ day $\left.{ }^{1}\right)$. The CD model also showed the highest $\mathrm{r}(0.65)$. According to $\mathrm{d}$ and $\mathrm{E}$, the best model was BC (Table 4). For SRA, a quite different pattern was observed: radiation estimated via the $\mathrm{BC}, \mathrm{CD}$ and $\mathrm{DB}$ models lead to simulated SRA values below the corresponding ones obtained by using observed radiation as model input. The HG and DCBB models showed an opposite tendency (Figure 2d). Taking into account the average of the deviance measures (RRMSE, RMSE, MAE and r) and similarity measures ( $\mathrm{d}$ and E) for all crop models output studied here, the $\mathrm{BC}$ model had the lowest 
(a)

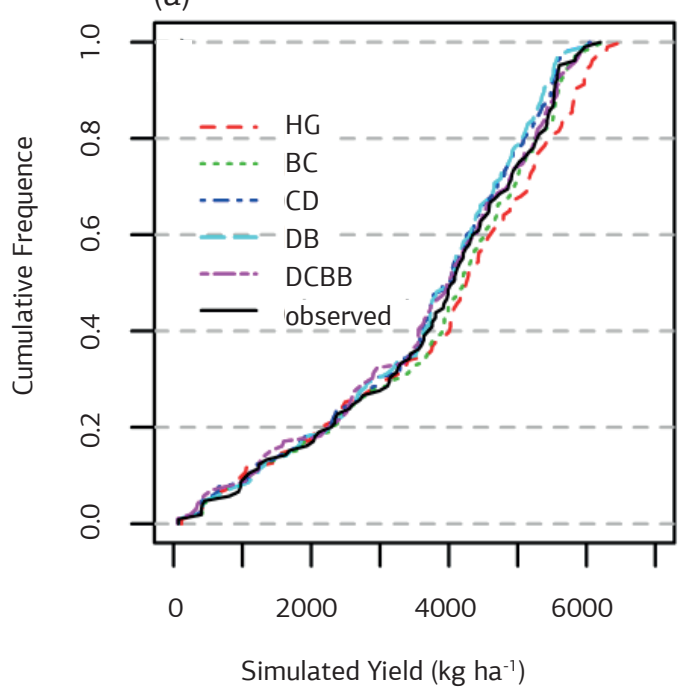

(b)

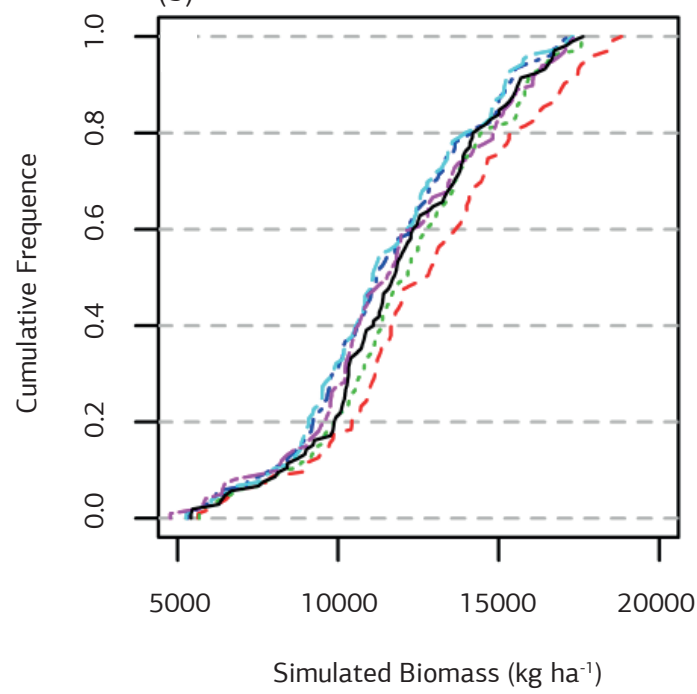

(c)

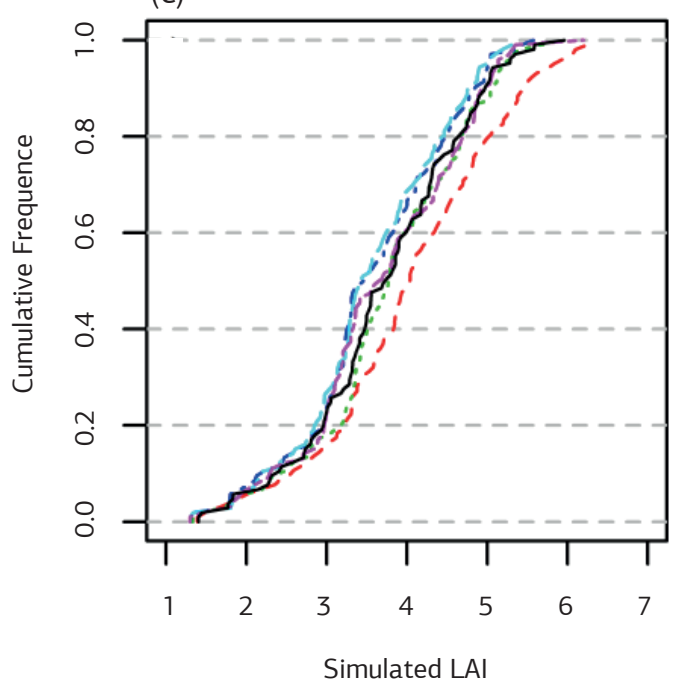

(d)

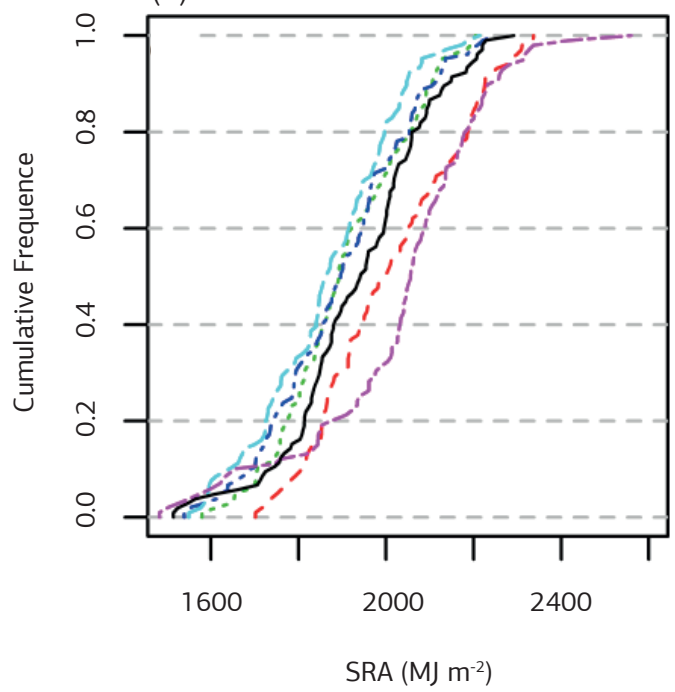

Figure 3. The estimated and observed empirical cumulative distribution function (ecdf) for the seasonal crop models output (a) yield, (b) biomass, (c) maximum leaf area index (LAI) and (d) accumulated solar radiation during crop cycle (SRA). BC: Bristow-Campbell; HG: Hargreaves; CD: Donatelli-Campbell; DB: Donatelli-Bellocchi and DCBB: modular model.

values for RRMSE, RMSE and MAE and the highest for $\mathrm{r}, \mathrm{d}$ and $\mathrm{E}$ (Table 4).

The ecdf curve for $Y_{R-o b s}$ and $Y_{R-\text { est }}$ seasonal crop model outputs were plotted in Figure 3. The quantile values derivate from ecdf for $Y_{R-\text { obs }}$ and $Y_{\text {R-est }}$ are showed in Table 5. For the seasonal crop model outputs yield, biomass and LAI, the ecdf curves for $Y_{R \text {-obs }}$ and $Y_{R \text {-est }}$ was quite similar (Figure $4 \mathrm{a}-\mathrm{c}$ ). It was also observed for the quantile values showed in table 5 . Based on the K-S test, the ecdf curves for $Y_{R \text {-obs }}$ and $Y_{\text {R-est }}$ did not differ statistically at $10 \%$ of significance (Table 5, p value). It means that for a limited water environment (no irrigation) solar radiation is not the main driven for yield, biomass and LAI and soil water available has an important role for these crop model outputs. Then, crop model outputs yield, biomass and LAI are not sensitive for the solar radiation models studied here (BC, $\mathrm{HG}, \mathrm{DCBB}$ and $\mathrm{CD}$ ). Based also in the $\mathrm{p}$ value from $\mathrm{K}-\mathrm{S}$ test (Table 5), the radiation model that showed the minimum vertical distance from $Y_{\text {R-obs }}$ and $Y_{R \text {-est }}$ ecdf curve for yield was BC and DCBB ( $>>0.05)$, for biomass and LAI was also BC model ( $p>0.05)$. For SRA, it was observed difference at level of $5 \%$ of significance between $Y_{\text {R-obs }}$ and $Y_{\text {R-est }}$ ecdf curve for DB, DCBB and HG solar radiation model (Table 5, p value). However, this difference in the accumulated solar radiation during the crop cycle was not enough to affected yield, biomass and LAI. 
Table 5. Quantile values (0, 25, 50, 75 and 100\%) and p values of Kolmogorov-Smirnov (K-S) test between observed and estimated empirical cumulative distribution function (ecdf) for crop models output (yield, biomass, maximum leaf area index (LAI) and solar radiation accumulated during crop cycle (SRA))

\begin{tabular}{|c|c|c|c|c|c|c|c|c|c|c|c|c|}
\hline \multirow{2}{*}{$\begin{array}{l}\text { Quantile } \\
\text { (\%) }\end{array}$} & \multicolumn{6}{|c|}{ Yield (kg ha-1) } & \multicolumn{6}{|c|}{ Biomass (kg ha ${ }^{-1}$ ) } \\
\hline & $Y_{R-\text { obs }}$ & BC & CD & DB & DCBB & HG & $\mathbf{Y}_{\mathrm{R} \text {-obs }}$ & BC & CD & DB & DCBB & HG \\
\hline 0 & 65 & 74 & 70 & 62 & 62 & 115 & 5413 & 5674 & 5303 & 5275 & 4780 & 5640 \\
\hline 25 & 2627 & 2649 & 2631 & 2631 & 2557 & 2610 & 10197 & 10353 & 9651 & 9493 & 9785 & 10918 \\
\hline 50 & 4050 & 4201 & 3969 & 4031 & 3983 & 4265 & 11717 & 12160 & 11191 & 11079 & 11517 & 12702 \\
\hline 75 & 5019 & 5076 & 4864 & 4868 & 5075 & 5255 & 13887 & 13996 & 13355 & 13394 & 14086 & 14753 \\
\hline 100 & 6203 & 6247 & 6052 & 6058 & 6123 & 6496 & 17626 & 17646 & 17176 & 17308 & 17363 & 18818 \\
\hline $\begin{array}{l}\text { K-S test } \\
\text { ( } p \text { value) }\end{array}$ & & 0.99 & 0.97 & 0.62 & 0.99 & 0.29 & & 0.92 & 0.40 & 0.24 & 0.69 & 0.12 \\
\hline \multirow{2}{*}{$\begin{array}{l}\text { Quantile } \\
\text { (\%) }\end{array}$} & \multicolumn{6}{|c|}{ LAI } & \multicolumn{6}{|c|}{ SRA (MJ m $\left.\mathrm{m}^{-2}\right)$} \\
\hline & $Y_{R-o b s}$ & BC & CD & DB & DCBB & HG & $Y_{\text {R-obs }}$ & BC & $C D$ & DB & DCBB & HG \\
\hline 0 & 1.40 & 1.33 & 1.30 & 1.30 & 1.30 & 1.39 & 1514 & 1579 & 1539 & 1550 & 1482 & 1702 \\
\hline 25 & 3.05 & 3.29 & 3.03 & 2.97 & 3.03 & 3.33 & 1830 & 1803 & 1785 & 1743 & 1940 & 1866 \\
\hline 50 & 3.70 & 3.77 & 3.49 & 3.42 & 3.61 & 4.03 & 1942 & 1892 & 1896 & 1861 & 2056 & 1994 \\
\hline 75 & 4.40 & 4.62 & 4.36 & 4.28 & 4.56 & 4.83 & 2048 & 2017 & 2013 & 1982 & 2162 & 2157 \\
\hline 100 & 5.96 & 5.96 & 5.57 & 5.41 & 6.20 & 6.32 & 2292 & 2204 & 2250 & 2213 & 2559 & 2337 \\
\hline $\begin{array}{l}\text { K-S test } \\
\text { ( } p \text { value) }\end{array}$ & & 0.87 & 0.18 & 0.34 & 0.65 & 0.15 & & 0.20 & 0.11 & 0.02 & $<0.01$ & 0.04 \\
\hline
\end{tabular}

$\mathrm{Y}_{\mathrm{R}-\mathrm{obs}}$ - crop model output obtained using observed radiation. BC: Bristow-Campbell. HG: Hargreaves. CD: Donatelli-Campbell. DB: Donatalli-Bellocchi and DCBB: modular model.

\section{CONCLUSION}

Five models for estimated daily solar radiation were tested in their agreement and showed similar accuracy $(\mathrm{r}=0.68$ to 0.75 , RMSE $=12$ to $14 \%$ ). For water limited environments (no irrigation) the crop model outputs yield, biomass and LAI is not sensitive for the uncertainties in radiation models studied here $\mathrm{BC}, \mathrm{CD}, \mathrm{DB}, \mathrm{HG}$ and DCBB). Among the radiation models studied here, the $\mathrm{BC}$ model show the minimum vertical distance between $Y_{\text {R-obs }}$ and $Y_{\text {R-est }}$ ecdf's (highest $p$ value) for all crop models outputs (yield, biomass, LAI and SRA).

\section{ACKNOWLEDGEMENTS}

To $\mathrm{CNPq}$, for the support of the research project n. $471838 / 2008$.

\section{REFERENCES}

AKPONIKPÈA, P.B.I.; MINETA, J.; GÉRARDC, B.; DEFOURNYA, P.; BIELDERSA, C.L. Spatial fields' dispersion as a farmer strategy to reduce agro-climatic risk at the household level in pearl millet-based systems in the Sahel: a modeling perspective. Agricultural and Forest Meteorology, v.151, p.215-227, 2011.

BALL, R.A.; PURCELL, L.C.; CAREY, S.K. Evaluation of solar radiation prediction models in North America. Agronomy Journal, v.96, p.391-397, 2004.

BECHINI, L.; DUCCO, G.; DONATELLI, M.; STEIN A. Modelling, interpolation and stochastic simulation in space and time of global solar radiation. Agriculture, Ecosystems and Environment, v.81, p.29-42, 2000.

BELLOCCHI, G.; DONATELLI, M.; FILA, G. Evaluation of estimated radiation data for calculating evapotranspiration and crop biomass. Italian Journal of Agronomy, v.7, p.95-102, 2003.

BOUMAN, B.A.M.; VAN LAAR, H.H. Description and evaluation of the rice growth model ORYZA2000 under nitrogenlimited conditions. Agricultural Systems, v.87, p.249-273, 2006.

BRISTOW, K.L.; CAMPBELL, G.S. On the relationship between incoming solar radiation and daily maximum and minimum temperature. Agricultural and Forest Meteorology, v.31, p.159-166, 1984.

DONATELLI, M.; ACUTIS M.; BELLOCCHI, G.; FILA G. New indices to quantify patterns of residuals produced by model estimates. Agronomy Journal, v.96, p.631-645, 2004.

DONATELLI, M.; BELLOCCHI, G.; FONTANA, F. RadEst 3: a software to estimate daily radiation data from commonly available meteorological variables. European Journal of Agronomy, v.18, p.363-367, 2003.

EMBRAPA. Centro Nacional de Pesquisa de Solos. Brazilian system of soil classification. Brasília, Brazil: Embrapa, 1999. 412p.

FARHADI BANSOULEH, B.; SHARIFI, M.A.; VAN KEULEN, H. Sensitivity analysis of performance of crop growth simulation models to daily solar radiation estimation methods in Iran. Energy Conversion and Management, v.50, p.2826-2836, 2009.

FLETCHER, A.L.; MOOT, D.J. Estimating daily solar radiation in New Zealand using air temperatures. New Zealand Journal of Crop and Horticultural Science, v.35, p. 147-157, 2007. 
GOUDRIAAN, J.; VAN LAAR, H.H. Modelling potential crop growth processes: current issues in production ecology. Dordrecht: Kluwer, 1994. 256p.

HARGREAVES, G.H. Responding to tropical climates. In: SLATER, L.E. (Ed.). Food and climate review 1980-81. Boulder: Aspen Institute for Humanistic Studies, 1981. p.29-32.

HARGREAVES, G.H.; SAMANI, Z.A. Reference crop evapotranspiration from temperature. Applied Engineering in Agriculture, v.1, p.96-99, 1985.

HEINEMANN, A.B.; DINGKUHN, M.; LUQUET, D.; COMBRES, J.C.; CHAPMAN, S. Characterization of drought stress environments for upland rice and maize in central Brazil. Euphytica, v.162, p. 395-410, 2008.

HUNT, L.A.; KUCHAR, L.; SWANTON, C.J. Estimation of solar radiation for use in crop modelling. Agricultural and Forest Meteorology, v.91, p.293-300, 1998.

JAMIESON, P.D.; PORTER, J.R.; WILSON, D.R. A test of the computer simulation model ARC-WHEAT1 on wheat crops grown in New Zealand. Field Crops Research, v.27, p.337-350, 1991.

KEATING, B.A.; CARBERRY, P.S.; HAMMER, G.L.; PROBERT, M.E.; ROBERTSON, M.J.; HOLZWORTH, D.; HUTH, N.I.; HARGREAVES, J.N.G.; MEINKE, H.; HOCHMAN, Z.; MCLEAN, G.; VERBURG, K.; SNOW, V.; DIMES, J.P.; SILBURN, M.; WANG, E.; BROWN, S.; BRISTOW, K.L.; ASSENG, S.; CHAPMAN, S., MCCOWN, R.L., FREEBAIRN, D.M.; SMITH, C.J. An overview of APSIM, a model designed for farming systems simulation. European Journal of Agronomy, v.18, p.267-288, 2003.

LEGATES, D.R.; MCCABE JR, G.J. Evaluating the use of "goodness-of-fit" measures in hydrologic and hydroclimatic model validation. Water Resources Research, v.35, p.233-241, 1999.

LIU, D.L.; SCOTT, B.J. Estimation of solar radiation in Australia from rainfall and temperature observations. Agricultural and Forest Meteorology, v.106, p.41-59, 2000.

LIU, X.; MEI, X.; LI, Y.; WANG, Q.; JENSEN, R.J.; ZHANG, Y.; PORTE, J.R. Validation of temperature-based global solar radiation models in China. Agricultural and Forest Meteorology, v.149, p.1433-1446, 2008.

LORENÇONI, R.; DOURADO NETO, D.; HEINEMANN, A.B. Calibration and evaluation of the ORYZA-APSIM crop model for upland rice in Brazil. Revista Ciência Agronômica, v.41, p.605-613, 2010.

MAIA, A.H.N.; MEINKE, H.; LENNOX, S.; STONE, R.C. Inferential, non-parametric statistics to assess quality of probabilistic forecast systems. Monthly Weather Review, v.135, p.351-362, 2007.

MAVROMATIS, T.T.; JAGTAP, S.S. Estimating solar radiation for crop modeling using temperature data from urban and rural stations. Climate Research, v.29, p.233-243, 2005.

MORIASI, D. N.; ARNOLD, J. G.; VAN LIEW, M. W.; BINGNER, R. L.; HARMEL, R. D.; VEITH T. L. Model evaluation guidelines for systematic quantification of accuracy in watershed simulations. Transactions of the ASABE, v.50, p.885-900, 2007.

NASH, J. E.; SUTCLIFFE, J.V. River flow forecasting through conceptual models part I - A discussion of principles. Journal of Hydrology, v.10, p.282-290, 1970.

TRNKA, M.; ZDENEK, Z.; EITZINGER, J.; DUBROVSKY, M. Global solar radiation in Central European lowlands estimated by various empirical formulae. Agricultural and Forest Meteorology, v.131, p.54-76, 2005.

WEISS, A.; HAYS, C.J. Simulation of daily solar irradiance. Agricultural and Forest Meteorology, v.123, p.187-199, 2004.

WILLMOTT, C.J. On the validation of models. Physical Geography, v.2, p.184-194, 1981.

WILLMOT, C.J. On the evaluation of model performance in physical geography. In: GAILE, G.L.; WILLMOT, C.J. (Ed.). Spatial statistics and models. Dordrecht: Reidel, 1984. p.443-460.

XIE, Y.; KINIRY, J.R.; WILLIAMS, J.R. The Almanac model's sensitivity to input variables. Agricultural Systems, v.78, p.1-16, 2003. 